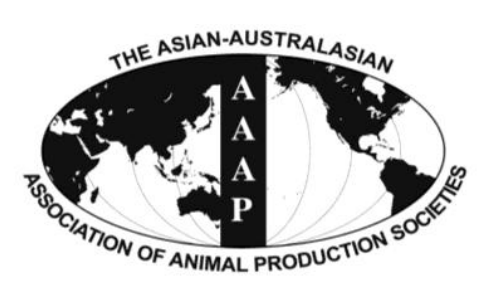

\title{
Energy and lleal Digestible Amino Acid Concentrations for Growing Pigs and Performance of Weanling Pigs Fed Fermented or Conventional Soybean Meal
}

\author{
Y. Wang, W. Q. Lu, D. F. Li, X. T. Liu, H. L. Wang, S. Niu, and X. S. Piao* \\ State Key Laboratory of Animal Nutrition, China Agricultural University, Beijing 100193, China
}

\begin{abstract}
A new strategy of co-inoculating Bacillus subtilis MA139 with Streptococcus thermophilus and Saccharomyces cerevisiae was used to produce fermented soybean meal (FSBM). Three experiments were conducted to determine the concentration of digestible energy (DE) and metabolizable energy (ME) (Exp. 1), apparent ileal digestibility (AID) and standardized ileal digestibility (SID) of amino acids (AA) (Exp. 2), and feeding value (Exp. 3) of FSBM produced by this new strategy (NFSB) compared with soybean meal (SBM) and conventionally available FSBM (Suprotein). In Exp. 1, twenty-four barrows (initial body weight [BW] of 32.2 $\pm 1.7 \mathrm{~kg}$ ) were randomly allotted to 1 of 4 diets with 6 replicates per diet. A corn basal diet and 3 diets based on a mixture of corn and 1 of 3 soybean products listed above were formulated and the DE and ME contents were determined by the difference method. The results showed that there were no differences in DE and ME between SBM and either FSBM product ( $p>0.05$ ). In Exp. 2, eight barrows (initial BW of $26.8 \pm 1.5 \mathrm{~kg}$ ) were fitted with ileal T-cannulaes and used in a replicated $4 \times 4$ Latin square design. Three corn-starch-based diets were formulated using each of the 3 soybean products as the sole source of AA. A nitrogen-free diet was also formulated to measure endogenous losses of AA. The results showed that the SID of all AA except arginine and histidine was similar for NFSB and SBM ( $p>0.05)$, but Suprotein had greater ( $p<0.05$ ) SID of most AA except lysine, aspartate, glycine and proline than NFSB. In Exp. 3, a total of 144 piglets (initial BW of $8.8 \pm 1.2 \mathrm{~kg}$ ) were blocked by weight and fed 1 of 4 diets including a control diet with $24 \%$ SBM as well as diets containing $6 \%$ and $12 \%$ NFSB or $12 \%$ Suprotein added at the expense of SBM. During d 15 to 28 , replacing SBM with $6 \%$ NFSB significantly improved average daily gain (ADG) and average daily feed intake (ADFI) $(\mathrm{p}<0.05)$ for nursery piglets. During the overall experiment, ADG of piglets fed diets containing 6\% NFSB was significantly greater $(\mathrm{p}<0.05)$ than that of piglets fed SBM. In conclusion, fermentation with the new strategy did not affect the energy content or the AID and the SID of AA in SBM. However, inclusion of $6 \%$ NFSB in diets fed to nursery piglets improved performance after weaning likely as a result of better nutritional status and reduced immunological challenge. (Key Words: Energy, Fermented Soybean Meal, Ileal Digestible Amino Acids, Performance, Pigs, Soybean Meal)
\end{abstract}

\section{INTRODUCTION}

Soybean meal (SBM) is the most common plant-derived protein source used in the swine and poultry industries (Cronwell, 2012). Its high lysine content, excellent nutrient availability and favorable palatability make it a good source of protein for use in swine diets. However, a variety of antinutritional factors interfere with digestion, absorption, and

\footnotetext{
* Corresponding Author: X. S. Piao. Tel: +86-10-62733588, Fax: +86-10-62733688, E-mail: piaoxsh@mafic.ac.cn

Submitted Sept. 28, 2013; Revised Dec. 10, 2013; Accepted Jan. 16, 2014
}

utilization of nutrients (Waldroup, 2012). Fermentation of SBM (FSBM) can remove trypsin inhibitors, oligosaccharides and phytic acid, supply partially digested soybean proteins and live microorganisms and enhance apparent total tract digestibility (ATTD) of nutrients (Egounlety and Aworh, 2003; Hong et al., 2004; Refstie et al., 2005; Feng et al., 2007). An increase in ileal digestibility of amino acids (AA) may also be observed in FSBM compared with SBM (Yun et al., 2004; Zhang et al., 2013). Concentrations of digestible energy (DE) and metabolizable energy (ME) may also be affected by fermentation (Rojas and Stein, 2013). Consequently, FSBM

Copyright @ 2014 by Asian-Australasian Journal of Animal Sciences This is an open-access article distributed under the terms of the Creative Commons Attribution Non-Commercial License (http://creativecommons.org/licenses/by-nc/3.0/), which permits unrestricted non-commercial use, distribution, and reproduction in any medium, provided the original work is properly cited. 
may be used to replace other high quality protein sources without adversely affecting the performance of nursery pigs (Kim et al., 2010).

In recent years, the global production of FSBM has increased. FSBM is produced by various microorganisms, including Rhizopus oligosporus, Aspergillus oryzae, Lactobacillus brevis, and Bacillus subtilis (Egounlety and Aworh, 2003; Hong et al., 2004; Refstie et al., 2005; Feng et al., 2007). Although both liquid-state fermentation (Frias et al., 2008) and solid-state fermentation (Liu et al., 2007) have been used to produce FSBM, solid-state fermentation is more widely used because of its lower energy consumption and reduced waste water production (Singhania et al., 2009).

During our previous studies, multi-layer polythene bags equipped with a gas-pressure opening valve (200610002389.9, State Intellectual Property Office of the People's Republic of China) were used to produce fermented compound pig feed (Hu et al., 2008), fermented SBM and wheat bran mixture (Ying et al., 2009) as well as fermented rapeseed meal (Chiang et al., 2010). The valve is designed to discharge internal air when the air pressure is increased by carbon dioxide metabolized by the aerobic bacteria, but the valve does not allow external air into the bag. With this technology, it is possible to co-incubate aerobic bacteria with anaerobic bacteria in the production of FSBM. Therefore, a combined starter culture of Streptococcus thermophilus, Bacillus subtilis MA139 and Saccharomyces cerevisiae was used to produce FSBM. S. cerevisiae is used to consume the oxygen inside the fermentation bag to create an anaerobic condition for $S$. thermophilus and B. subtilis MA139. B. subtilis MA139 was successfully isolated in our previous study (Guo et al., 2006) and is capable of secreting several active components such as $\beta$-mannanase and $\beta$-glucanase (Qiao et al., 2009; 2010). B. subtilis MA139 is also able to synthesize antimicrobial substances and prevent the growth of enterobacteriaceae (Ying et al., 2009).

In the current study, this innovative strategy was used to produce solid-state FSBM. The objective of the current experiment was to compare the energy content and standardized ileal digestibility (SID) and apparent ileal digestibility (AID) of AA in FSBM produced by this new strategy (NFSB) with SBM and a commercially available FSBM (Suprotein) and to evaluate their use in diets fed to nursery piglets.

\section{MATERIALS AND METHODS}

\section{Fermentation of soybean meal}

Streptococcus thermophiles (CGMCC No. 1.2471) and Saccharomyces cerevisiae (CGMCC No. 2.1793) were purchased from the Microbial Institute of the Chinese
Academy of Sciences (Beijing, China). Bacillus subtilis MA139 was obtained from the National Key Laboratory on Animal Nutrition of China (Beijing, China). $S$. thermophilus was cultured in de Man, Rogosa and Sharpmedia at $37^{\circ} \mathrm{C}$ for 24 h. S. cerevisae and B. subtilis MA139 were grown in yeast peptone dextrose and mixed nutrition broth, respectively, in a rotary shaker (225 $\mathrm{rev} / \mathrm{min}$ ) at $30^{\circ} \mathrm{C}$ for $24 \mathrm{~h}$. After incubation, the cells were washed twice in sterile saline solution and inoculated to give a final inoculant of $1 \times 10^{7} \mathrm{cfu} / \mathrm{mL}$. The liquid starter culture was prepared by mixing equal volumes of the three inoculants before fermentation.

Defatted and dehulled SBM was purchased from the Yihai Kerry Investment Company (Shanghai, China) and was utilized as the substrate for fermentation after being milled (40 mesh). Neutral protease (B. subtilis 1.398) and acid protease (A. niger 3350) in powder form, with an activity of 50,000 IU/g, were obtained from Bosar Biotechnology (Beijing, China). Neutral protease was mixed with acid protease in a ratio of 3:1 to prepare the protease mixture. Natural brown sugar containing 96.2\% sucrose was purchased from China Oil \& Foodstuffs Corporation (Beijing, China). Liquid starter culture (10\% $\mathrm{v} / \mathrm{w}$ ) was added to the SBM, which was fortified with $0.5 \%$ $(\mathrm{w} / \mathrm{w})$ brown sugar and $0.3 \%(\mathrm{w} / \mathrm{w})$ protease mixture. Sterile distilled water was added to achieve a $40 \%$ initial moisture content. Fermentation of SBM was performed in multi-layer polythene bags (500 g capacity) equipped with a gas-pressure opening valve at $40^{\circ} \mathrm{C}$ for 5 days. After fermentation, NFSB was dried by hot air and ground with a hammer mill $(1.0 \mathrm{~mm})$ and frozen until mixed in the diets. The commercially available FSBM (Suprotein, Beijing Gold-tide Biotechnology Company, Beijing, China) used in this experiment was produced using a mixture of bacterial and fungal strains in solid-state fermentation.

\section{Animals and experimental design}

The experimental protocols used in these studies were approved by the Institutional Animal Care and Use Committee of China Agricultural University (Beijing, China).

Experiment 1: Twenty-four barrows (Duroc $\times$ Landrace $\times$ Large White) with an initial body weight (BW) of $32.2 \pm 1.7$ $\mathrm{kg}$ were used to determine the DE and ME content of SBM and two FSBM products. Pigs were randomly assigned to 1 of 4 dietary treatments with 6 replications per diet. The basal diet contained $96 \%$ corn with the remainder of the diet comprised of vitamins and minerals. Three test diets were formulated to contain $24 \%$ of SBM and the two FSBM products which replaced $25 \%$ of the energy supplied by corn (Table 2). Vitamins and minerals were supplemented in all diets to meet or exceed the estimated nutrient requirements for growing pigs recommended by NRC 
(1998).

Feces and urine collection was conducted according to the methods described by Song et al. (2003) and Ren et al. (2011). The experiment consisted of $5 \mathrm{~d}$ for adaptation to the diets followed by $5 \mathrm{~d}$ of total collection of feces and urine. The quantity of feed provided per pig each day was calculated as $4 \%$ of the $\mathrm{BW}$ at the beginning of the experiment (Adeola, 2001) and was divided into 2 equal meals. Pigs were fed at 8:00 and 17:00 $\mathrm{h}$ and water was available ad libitum. Feces were collected, pooled for the 5 -d collection period, and stored at $-20^{\circ} \mathrm{C}$. Urine was collected into plastic buckets containing $50 \mathrm{~mL}$ of $6 \mathrm{~N} \mathrm{HCl}$. Ten percent of each days output (volume basis) was stored at $-20^{\circ} \mathrm{C}$ and pooled within the collection period. At the end of the experiment, feces and urine samples were thawed and mixed, and a subsample was obtained for chemical analysis.

Experiment 2: Eight barrows (initial BW of $26.8 \pm 1.5$ $\mathrm{kg}$ ) were randomly allotted to a replicated $4 \times 4$ Latin Square Design with 4 diets and 4 periods balanced for carryover effects (Kim and Stein, 2009). A T-cannula was surgically installed in the distal ileum of each pig (Stein et al., 1998). Four diets were prepared (Tables 3 and 4). The test diets contained $25 \%$ of 1 of the 3 soybean products as the sole dietary source of AA. A nitrogen-free diet was used to measure basal endogenous losses of AA and crude protein (CP). All diets contained $0.3 \%$ chromic oxide as an inert marker. Acetate cellulose (Chemical Reagents Company, Beijing, China) was included in the nitrogen-free diet to increase the concentration of crude fiber. Magnesium oxide and potassium carbonate were used to provide additional minerals. Vitamins and minerals were included in all diets to meet or exceed the estimated nutrient requirements for growing pigs recommended by NRC (1998).

The feeding procedure was similar to that described for Exp. 1. Each 7-d period consisted of a 5-d adaption period followed by $2 \mathrm{~d}$ (8:00 to 17:00) for collection of ileal digesta. Ileal digesta was collected by attaching a plastic bag to the cannula as described by Stein et al. (1998). At the end of the experiment, samples were thawed, mixed within animal and diet, and a subsample was obtained. Subsamples were lyophilized in a vacuum-freeze dryer (Tofflon Freezing Drying Systems, Shanghai, China), ground through a $1 \mathrm{~mm}$ screen and used for chemical analysis.

Experiment 3: A total of 144 crossbred pigs (Duroc $\times$ Landrace $\times$ Large White; initial BW of $8.8 \pm 1.2 \mathrm{~kg}$ ) were included in a $28-\mathrm{d}$ study. Pigs were blocked by initial $\mathrm{BW}$, equalized for sex, and randomly allotted to 1 of 4 treatments with 6 replicate pens and 6 pigs per pen. The dietary treatments were a control diet with $24 \%$ SBM, a test diet with 6\% NFSB (NFSB-6), a test diet with 12\% NFSB (NFSB-12) and a test diet with $12 \%$ Suprotein (Suprotein12) added at the expense of SBM. The four diets were formulated to contain equal SID lysine and DE concentrations. The SID lysine contents and DE values used for SBM, NFSB, and Suprotein were obtained from Exp. 1 and 2, whereas those values for fishmeal, whey powder and soybean oil were obtained from the NRC (2012).

Pigs were housed in an environmentally controlled nursery room. The temperature of the nursery room was set initially at $28^{\circ} \mathrm{C}$ and was reduced approximately by $1.5^{\circ} \mathrm{C}$ each week thereafter. Each pen was $1.2 \times 1.5 \mathrm{~m}$ and equipped with one drinking nipple and one feeder. Pigs were weighed, and feed disappearance was determined on $\mathrm{d} 7,14$, and 28 to determine average daily gain (ADG), average daily feed intake (ADFI) and gain-to-feed ratio (G:F).

\section{Chemical analysis}

The SBM and FSBM products, used in this study were analyzed for dry matter (DM), CP, ether extract, ash, calcium, phosphorus, and crude fiber using the methods of the AOAC (2000). Neutral detergent fiber (NDF) and acid detergent fiber (ADF) were determined using fiber bags and fiber analyzer equipment (Fiber Analyzer, Ankom Technology, Macedon, NY, USA) following a modification of the procedure of van Soest et al. (1991). Gross energy of the soybean products, diets, feces and urine were analyzed by an adiabatic oxygen bomb calorimeter (Parr Instruments, Moline, IL, US). Amino acid composition of soybean products, diets and ileal digesta was determined according to the procedures of AOAC (2000). Samples were hydrolyzed before analysis with $6 \mathrm{~N} \mathrm{HCl}$ for $24 \mathrm{~h}$ at $110^{\circ} \mathrm{C}$ and analyzed for 15 AA with an Automatic Amino Acid Analyzer (L-8800 Hitachi Automatic Amino Acid Analyzer, Tokyo, Japan). After cold performic acid oxidation overnight and hydrolysis with $7.5 \mathrm{~N} \mathrm{HCl}$ for $24 \mathrm{~h}$ at $110^{\circ} \mathrm{C}$, methionine and cystine were analyzed as methionine sulfone and cysteic acid. Tryptophan was determined after $\mathrm{LiOH}$ hydrolysis for $22 \mathrm{~h}$ at $110^{\circ} \mathrm{C}$ by High Performance Liquid Chromatography (Agilent 1200 Series, Santa Clara, CA, USA). The chromium concentration of diets and ileal digesta samples were determined using a Polarized Zeeman Atomic Absorption Spectrometer (Hitachi Z2000, Tokyo, Japan) according to Williams et al. (1962).

Ten $\mathrm{g}$ of each of the three soybean products were dissolved in $100 \mathrm{~mL}$ distilled water and then centrifuged at $4,000 \times g$ for $5 \mathrm{~min}$, and the $\mathrm{pH}$ of the supernatant was measured. A commercially available lactic acid enzymology assay kit was used according to the manufacturer's protocol (Nanjing Jiancheng Bio Company, Nanjing, China). The portion of protein that was soluble in $10 \%$ trichloroacetic acid (TCA) was analyzed with the ninhydrin reaction using a Spectrophotometer (Jenway, Stone, Staffordshire, UK) following the procedure of West (2004). The contents of glycinin and $\beta$-conglycinin were analyzed by a competitive ELISA developed in our laboratory (You et al., 2008; Ma et al., 2010). 
Protein separation in the three soybean products was performed by Tricine-SDS-PAGE according to the method of Schägger (2006) with $10 \%$ separating gels. The scanned photos of electrophoresis gels were analyzed by Bio-Rad Quantity One Software (Bio-Rad, Hercules, CA, USA) to measure the density of each band. The bands were classified as large (60 $\mathrm{kDa}$ and greater), medium (20 to $60 \mathrm{kDa})$, and small fractions (less than $20 \mathrm{kDa}$ ). The amount of each peptide in each class was expressed as a percentage of the total protein in the sample.

\section{Calculations and statistical analysis}

Energy values that were determined from the excretion of gross energy (GE) in the feces and urine were subtracted from the intake of GE to calculate DE and ME for each diet (Adeola, 2001). The DE and ME in the corn diet were divided by 0.96 to calculate the DE and ME in corn. The contributions of $\mathrm{DE}$ and $\mathrm{ME}$ from corn to the diets containing soybean products were then calculated and subtracted from the total DE and ME of these diets, and the concentrations of $\mathrm{DE}$ and $\mathrm{ME}$ in soybean products were calculated by difference (Adeola, 2001). AID and SID values of the soybean products were calculated according to Stein et al. (2007). Data for Exp. 1 were analyzed using the general linear model (GLM) procedure of SAS (SAS Institute, Cary, NC, USA) with pig as the experimental unit. If a significant treatment effect was detected, means were separated using Student Neuman Keul's Multiple Range Test. Data from Exp. 2 were analyzed using the Proc-Mixed procedure of SAS with each pig as the experimental unit. The statistical model for Exp. 2 had treatment as a fixed effect and period and pig as random effects. Data for Exp. 3 were analyzed using the GLM procedure of SAS for a randomized complete block design. The pen was considered the experimental unit. Separation of means was accomplished using Student Neuman Keul's Multiple Range Test. Probability values less than 0.05 were considered significant, and values between 0.05 and 0.10 were considered trends.

\section{RESULTS}

\section{Nutrient composition}

The concentration of most nutrients in NFSB was slightly higher than in SBM (Table 1). Suprotein contained more ether extract than NFSB, but less NDF, tryptophan, and aspartate. The FSBM products contained a larger amount of lactic acid with a lower $\mathrm{pH}$ compared with SBM. Concentration of lactic acid in NFSB was higher than in Suprotein $^{\circledR}$ while the $\mathrm{pH}$ of NFSB was lower. The concentration of glycinin and $\beta$-conglycinin were lower in the FSBM products than in SBM while Suprotein contained less glycinin and $\beta$-conglycinin than NFSB. Peptide size
Table 1. Analyzed composition of soybean products ( $\%$ as-fed $)^{1}$

\begin{tabular}{|c|c|c|c|}
\hline & SBM & NFSB & Suprotein $^{2}$ \\
\hline \multicolumn{4}{|l|}{ Item } \\
\hline DM & 90.81 & 88.06 & 92.93 \\
\hline $\mathrm{GE}(\mathrm{MJ} / \mathrm{kg})$ & 17.46 & 17.67 & 18.23 \\
\hline $\mathrm{CP}$ & 48.06 & 49.68 & 50.07 \\
\hline Ether extract & 0.79 & 0.87 & 2.14 \\
\hline Crude fiber & 3.56 & 4.12 & 5.20 \\
\hline NDF & 18.03 & 19.08 & 12.16 \\
\hline $\mathrm{ADF}$ & 6.64 & 6.65 & 5.99 \\
\hline Ash & 6.33 & 6.65 & 7.02 \\
\hline Calcium & 0.23 & 0.27 & 0.33 \\
\hline Total phosphorus & 0.82 & 0.89 & 0.70 \\
\hline \multicolumn{4}{|l|}{ Indispensable AA } \\
\hline Arginine & 3.15 & 2.95 & 3.42 \\
\hline Histidine & 1.13 & 1.14 & 1.44 \\
\hline Isoleucine & 2.07 & 2.13 & 2.14 \\
\hline Leucine & 3.41 & 3.54 & 3.71 \\
\hline Lysine & 2.77 & 2.72 & 2.95 \\
\hline Methionine & 0.65 & 0.66 & 0.68 \\
\hline Phenylalanine & 2.23 & 2.28 & 2.47 \\
\hline Threonine & 1.71 & 1.83 & 1.91 \\
\hline Tryptophan & 0.65 & 0.64 & 0.17 \\
\hline Valine & 2.07 & 2.17 & 2.30 \\
\hline \multicolumn{4}{|l|}{ Dispensable AA } \\
\hline Alanine & 1.91 & 2.12 & 2.34 \\
\hline Aspartate & 4.98 & 5.22 & 4.44 \\
\hline Cystine & 0.68 & 0.69 & 0.66 \\
\hline Glutamic acid & 7.64 & 8.10 & 8.35 \\
\hline Glycine & 1.85 & 1.99 & 2.05 \\
\hline Proline & 2.50 & 2.51 & 2.67 \\
\hline Serine & 2.13 & 2.30 & 2.64 \\
\hline Tyrosine & 1.50 & 1.65 & 1.57 \\
\hline $\mathrm{pH}$ & 6.5 & 5.0 & 5.5 \\
\hline Lactate acid (mmol/kg) & 23.8 & 157.6 & 146.9 \\
\hline$\beta$-Conglycinin (mg/g) & 66.8 & 39.5 & 28.2 \\
\hline Glycinin (mg/g) & 85.5 & 32.3 & 19.2 \\
\hline $\begin{array}{l}\text { Trichloroacetic acid } \\
\text { soluble protein }(\mu \mathrm{mole} / \mathrm{g})\end{array}$ & 76.6 & 270.0 & 144.6 \\
\hline \multicolumn{4}{|l|}{ Peptide size distribution (\%) } \\
\hline $60 \mathrm{kDa}$ and higher & 24.4 & 9.3 & 9.7 \\
\hline 20 to $60 \mathrm{kDa}$ & 53.4 & 49.1 & 30.8 \\
\hline $20 \mathrm{kDa}$ and lower & 22.2 & 41.6 & 59.5 \\
\hline
\end{tabular}

SBM, soybean meal; NFSB, fermented soybean meal produced by new strategy; DM, dry matter; GE, gross energy; CP, crude protein; NDF, neutral detergent fiber; $\mathrm{ADF}$, acid detergent fiber; $\mathrm{AA}$, amino acids.

${ }^{1}$ Values represent the mean of one sample analyzed in duplicate.

${ }^{2}$ Suprotein $=$ Conversional fermented soybean meal purchased from Beijing Gold-tide Biotechnology Co., Ltd. (Beijing, China).

distribution was changed after fermentation and the percentage of large peptides (60 $\mathrm{kDa}$ and higher) was lower in the two FSBM products than in SBM. After fermentation, the percentage of middle peptides (20 to $60 \mathrm{kDa}$ ) was 
Table 2. Ingredient composition of the experimental diets (\% asfed)

\begin{tabular}{lcccc}
\hline & SBM & NFSB & Suprotein & Basal diet \\
\hline Ingredient (\%) & & & & \\
Corn & 72.00 & 72.00 & 72.00 & 96.00 \\
SBM & 24.00 & - & - & - \\
NSFB & - & 24.00 & - & - \\
Suprotein & \\
Dicalcium & - & - & 24.00 & - \\
$\quad$ phosphate & 1.80 & 1.80 & 1.80 & 1.80 \\
Limestone & & & & \\
Salt & 0.80 & 0.80 & 0.80 & 0.80 \\
Wheat rice stone & 0.30 & 0.30 & 0.30 & 0.30 \\
Vitamin-mineral & 0.60 & 0.60 & 0.60 & 0.60 \\
$\quad$ premix & 0.50 & 0.50 & 0.50 & 0.50 \\
Analyzed composition & & & & \\
DM & & & & \\
GE, MJ/kg & 88.87 & 88.63 & 89.12 & 88.12 \\
CP & 15.82 & 15.78 & 16.02 & 15.47 \\
Ether extract & 17.22 & 17.24 & 18.14 & 7.72 \\
Crude fiber & 2.30 & 2.59 & 2.65 & 2.65 \\
NDF & 2.42 & 2.47 & 2.85 & 2.21 \\
ADF & 10.58 & 11.44 & 11.96 & 9.97 \\
Ash & 2.72 & 2.83 & 3.24 & 2.16 \\
Calcium & 5.17 & 5.46 & 5.43 & 4.26 \\
Total phosphorus & 0.73 & 0.81 & 0.74 & 0.70 \\
NBM & 0.65 & 0.69 & 0.67 & 0.53 \\
\hline
\end{tabular}

SBM, soybean meal; NFSB, fermented soybean meal produced by new strategy; DM, dry matter; GE, gross energy; $\mathrm{CP}$, crude protein; NDF, neutral detergent fiber; $\mathrm{ADF}$, acid detergent fiber.

${ }^{1}$ Suprotein $=$ Conversional fermented soybean meal purchased from Beijing Gold-tide Biotechnology Co., Ltd. (Beijing, China).

${ }^{2}$ Provided per kg of complete diet: $\mathrm{Mn}(\mathrm{MnO}), 50 \mathrm{mg} ; \mathrm{Fe}\left(\mathrm{FeSO}_{4} \cdot \mathrm{H}_{2} \mathrm{O}\right)$, $125 \mathrm{mg}$; $\mathrm{Zn}(\mathrm{ZnO}), 125 \mathrm{mg}$; $\mathrm{Cu}\left(\mathrm{CuSO}_{4} \cdot 5 \mathrm{H}_{2} \mathrm{O}\right), 150 \mathrm{mg}$; I (KI), $50 \mathrm{mg}$; Se $\left(\mathrm{Na}_{2} \mathrm{SeO}_{3}\right), 0.48 \mathrm{mg}$; retinyl acetate, 4,500 IU; cholecalciferol, 1,350 IU; DL- $\alpha$-tocopheryl acetate, $13.5 \mathrm{mg}$; menadione sodium bisulfite complex, $2.7 \mathrm{mg}$; niacin, $18 \mathrm{mg}$; vitamin $\mathrm{B}_{12}, 27.6 \mathrm{mg}$; thiamine, $0.6 \mathrm{mg}$; pyridoxine, $0.9 \mathrm{mg}$; riboflavin, $1.8 \mathrm{mg}$; D-calcium-pantothenate, 10.8 $\mathrm{mg}$; nicotinic acid, $30.3 \mathrm{mg}$; choline chloride, $210 \mathrm{mg}$.

higher in NFSB than in Suprotein. However, the percentage of small peptides (20 kDa and lower) was lower in NFSB than in Suprotein. TCA soluble protein content was used to measure the portion of proteins soluble in TCA, which typically represents polypeptide of less than 10 AA and free AA. The concentrations of TCA soluble proteins were 76.6, 270.0, and $144.6 \mu \mathrm{mole} / \mathrm{g}$ in SBM, NFSB, and Suprotein, respectively.

Experiment 1: The DE and ME content, ATTD of GE and the $\mathrm{ME}$ to $\mathrm{DE}$ ratio in the soybean products are presented in Table 6 . There were no significant differences in these criteria among the different soybean products. The $\mathrm{DE}$ and ME for SBM were 16.94 and $16.56 \mathrm{MJ} / \mathrm{kg} \mathrm{DM}$, respectively.

Experiment 2: The AID of $\mathrm{CP}$ and most AA in NFSB was not different from the AID in SBM, except for the AID
Table 3. Diet composition of Exp. 2 (\% as-fed)

\begin{tabular}{|c|c|c|c|c|}
\hline Ingredients (\%) & SBM & NFSB & Suprotein & $\begin{array}{c}\mathrm{N} \text {-free } \\
\text { diet }\end{array}$ \\
\hline Cornstarch & 53.40 & 53.45 & 53.35 & 68.25 \\
\hline SBM & 25.00 & - & - & - \\
\hline NFSB & - & 25.00 & - & - \\
\hline Suprotein $^{1}$ & - & - & 25.00 & - \\
\hline Sucrose & 15.00 & 15.00 & 15.00 & 20.00 \\
\hline Acetate cellulose $\mathrm{e}^{2}$ & - & - & - & 4.00 \\
\hline Soybean oil & 3.00 & 3.00 & 3.00 & 3.00 \\
\hline Limestone & 0.45 & 0.50 & 0.30 & - \\
\hline Dicalcium phosphate & 1.90 & 1.80 & 2.10 & 3.10 \\
\hline Salt & 0.45 & 0.45 & 0.45 & 0.45 \\
\hline Magnesium oxide & - & - & - & 0.10 \\
\hline Potassium carbonate & - & - & - & 0.30 \\
\hline Chromic oxide & 0.30 & 0.30 & 0.30 & 0.30 \\
\hline $\begin{array}{l}\text { Mineral and } \\
\text { vitamin premix }\end{array}$ & 0.50 & 0.50 & 0.50 & 0.50 \\
\hline \multicolumn{5}{|c|}{ 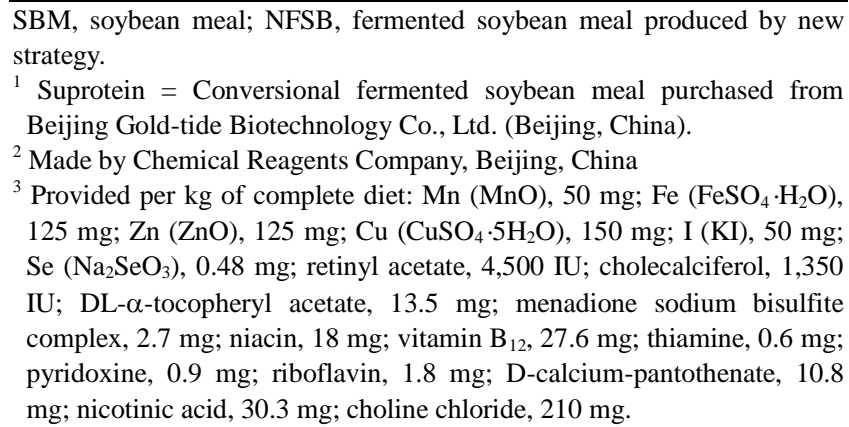 } \\
\hline
\end{tabular}

of arginine, histidine and serine, which was lower $(\mathrm{p}<0.05)$ in NFSB than in SBM (Table 7). With the exception of the AID of lysine, glycine and proline, the AID of CP and most AA in Suprotein was higher than in NFSB $(p<0.05)$.

The SID of CP and AA in the three soybean products are summarized in Table 8. The SID of arginine and histidine in NFSB was lower $(p<0.05)$ than in SBM, but the SID for CP and other AA in NFSB were not different from the SID of $\mathrm{CP}$ and AA in SBM. The SID for most AA in Suprotein was higher than the SID of AA in NFSB $(\mathrm{p}<0.05)$. However, the SID of lysine, aspartate, glycine and proline in Suprotein were not different from the SID in NFSB.

Experiment 3: Table 9 shows the ADFI, ADG, and G:F data computed for d 1 to 14 , d 15 to 28 and the overall experiment. Initial BW of piglets did not differ among treatments. There was no difference in ADG, ADFI, and G:F among treatments during d 1 to 14. During d 15 to 28, ADG of NFSB-6 was greater $(\mathrm{p}<0.05)$ than the control and Suprotein-12 whereas ADG of NFSB-6 was not different from NFSB-12. Average daily feed intake of NFSB-12 and Suprotein-12 did not differ from the control; However, ADFI of NFSB-6 was greater than the control $(\mathrm{p}<0.05)$. Gain-to-feed ratio was not different among treatments. During the overall experiment, there were no differences in 
Table 4. Analyzed composition of the experimental diets of Exp. 2 (\% as-fed)

\begin{tabular}{|c|c|c|c|c|}
\hline & SBM & NFSB & Suprotein ${ }^{1}$ & $\begin{array}{c}\mathrm{N} \text {-free } \\
\text { diet }\end{array}$ \\
\hline$\overline{\mathrm{DM}}$ & 91.89 & 91.40 & 92.06 & 91.60 \\
\hline $\mathrm{CP}$ & 12.24 & 13.28 & 13.48 & - \\
\hline \multicolumn{5}{|l|}{ Indispensable AA } \\
\hline Arginine & 0.93 & 0.87 & 1.00 & - \\
\hline Histidine & 0.33 & 0.34 & 0.36 & - \\
\hline Isoleucine & 0.53 & 0.57 & 0.62 & - \\
\hline Leucine & 0.94 & 0.99 & 1.07 & - \\
\hline Lysine & 0.76 & 0.74 & 0.78 & - \\
\hline Methionine & 0.15 & 0.16 & 0.17 & - \\
\hline Phenylalanine & 0.61 & 0.63 & 0.71 & - \\
\hline Threonine & 0.50 & 0.53 & 0.57 & - \\
\hline Tryptophan & 0.13 & 0.14 & 0.15 & - \\
\hline Valine & 0.59 & 0.63 & 0.67 & - \\
\hline \multicolumn{5}{|l|}{ Dispensable AA } \\
\hline Alanine & 0.53 & 0.58 & 0.61 & - \\
\hline Aspartate & 1.40 & 1.50 & 1.58 & - \\
\hline Cystine & 0.20 & 0.21 & 0.22 & - \\
\hline Glutamic acid & 2.25 & 2.39 & 2.58 & - \\
\hline Glycine & 0.54 & 0.58 & 0.62 & - \\
\hline Proline & 0.62 & 0.71 & 0.76 & - \\
\hline Serine & 0.61 & 0.65 & 0.70 & - \\
\hline Tyrosine & 0.31 & 0.33 & 0.37 & - \\
\hline
\end{tabular}

SBM, soybean meal; NFSB, fermented soybean meal produced by new strategy; DM, dry matter; $\mathrm{CP}$, crude protein; AA, amino acids.

${ }^{1}$ Suprotein = Conversional fermented soybean meal purchased from Beijing Gold-tide Biotechnology Co., Ltd. (Beijing, China).

ADFI and G:F among treatments; However, ADG of NFSB6 was greater $(p<0.05)$ than the control and Suprotein- 12 .

\section{DISCUSSION}

The concentrations of $\mathrm{CP}$ and AA in SBM were similar to the concentrations reported by Woodworth et al. (2001) and NRC (2012), whereas the concentration of NDF was greater in SBM than the concentration reported by NRC (2012). Fermentation of SBM by this new strategy slightly increased the $\mathrm{CP}$ and AA concentrations, which is contrary to observations from other experiments (Frias et al., 2008; Zhang et al., 2013). Differences in the starter strains, fermentation conditions, and drying methods might contribute to the different nutrient composition of FSBM. In this study, FSBM products contained more lactate acid, TCA soluble protein, and less glycinin and $\beta$-conglycinin than SBM. After fermentation, the size of peptides in SBM decreased. These improved biochemical characteristics of FSBM products can be beneficial to nursery piglets with potentially limited gastric $\mathrm{HCl}$ secretion needed for protein digestion (Cranwell, 1985).

From the results of Exp. 1, the DE (16.31 MJ/kg DM) and ME (15.99 MJ/kg DM) content of corn were close to the values of NRC (2012). The DE value for SBM (16.94 $\mathrm{MJ} / \mathrm{kg} \mathrm{DM}$ ) is similar to the published value of NRC (2012). However, the ME value for SBM $(16.56 \mathrm{MJ} / \mathrm{kg} \mathrm{DM})$ is higher than the published value of NRC (2012). The ME to DE ratio of SBM was $94.50 \%$ in this study is nearly concordant with the result published by Noblet and Henry (1993) where the ME to DE ratio of SBM was $93.5 \%$.

The results from the present experiment demonstrate that there were no differences in the $\mathrm{DE}$ and $\mathrm{ME}$ between SBM and NFSB despite the fact that glycinin and $\beta$ conglycinin were degraded and the percentage of small peptides increased after fermentation. Zhang et al. (2013) suggested that no differences in DE and ME were observed between FSBM and SBM, whereas more digestible components were produced by fermentation. Goebel and Stein (2011) indicated that enzyme treatment decreased the concentration of oligosaccharides, trypsin inhibitor, glycinin and $\beta$-conglycinin in SBM. However, the concentrations of $\mathrm{DE}$ and ME were not affected. Removal of sucrose and oligosaccharides from SBM by fermentation results in a greater concentration of $\mathrm{CP}$, ether extract, $\mathrm{ADF}$, and $\mathrm{NDF}$. The concentrations of $\mathrm{CP}$ and ether extract were greater in NFSB than in SBM and NFSB also contained more ash, $\mathrm{ADF}$, and NDF than SBM, which is likely the reason that no differences in DE and ME were observed between NFSB and SBM.

AID and SID of AA in SBM are similar to or greater than those reported in other studies (Cervantes-Pahm and Stein, 2010; NRC, 2012; Zhang et al., 2013). The absorption rate of small peptides is greater than for free AA (Gilbert et al., 2008) and an increased concentration of small peptides was expected to improve the digestibility of NFSB. Moreover, the low concentrations of anti-nutritional factors in NFSB were expected to contribute to an increased digestibility of AA when fed to young animals (Lalles et al., 1996). However, the similar AID and SID of most AA with the exception of arginine and histidine in NFSB compared with SBM was observed in the present experiment. Several factors may account for this phenomenon. First, excessive heat during drying process may bind AA and protein to other compounds, such as fiber, and thus decrease digestibility of AA (Evans and Butts, 1948). The Lysine to CP ratio was $5.76 \%$ in SBM but was $5.48 \%$ in NFSB, which indicated that the batch of NFSB used in the present experiment may have been slightly overheated. The second factor may be due to the greater NDF content compared with SBM. Lenis et al. (1996) demonstrated that increased concentrations of NDF decrease AA digestibility. The reason for the greater digestibility of most AA in Suprotein than in NFSB may be that the concentration of NDF and ADF in Suprotein was lower than in NFSB. In the Suprotein, there was also an increase in the concentration of 
Table 5. Ingredient composition and chemical analysis of diets containing soybean products used in Exp. 3 (\% as-fed)

\begin{tabular}{|c|c|c|c|c|}
\hline & SBM & NFSB-6 & NFSB-12 & Suprotein-12 \\
\hline \multicolumn{5}{|l|}{ Ingredient } \\
\hline Corn & 61.65 & 61.64 & 61.23 & 61.69 \\
\hline SBM & 24.00 & 18.00 & 12.00 & 12.00 \\
\hline NFSB & - & 6.00 & 12.00 & - \\
\hline Suprotein $^{1}$ & - & - & - & 12.00 \\
\hline Fish meal $(65 \% \mathrm{CP})$ & 3.00 & 3.00 & 3.00 & 3.00 \\
\hline Whey powder $(12 \% \mathrm{CP})$ & 8.00 & 8.00 & 8.00 & 8.00 \\
\hline Soybean oil & - & - & 0.40 & - \\
\hline Dicalcium phosphate & 0.78 & 0.78 & 0.78 & 0.75 \\
\hline Limestone & 0.80 & 0.80 & 0.80 & 0.80 \\
\hline Salt & 0.35 & 0.35 & 0.35 & 0.35 \\
\hline L-lysine $\mathrm{HCl}(78 \%)$ & 0.21 & 0.23 & 0.24 & 0.19 \\
\hline L-threonine (98\%) & 0.06 & 0.05 & 0.05 & 0.03 \\
\hline L-tryptophan (98\%) & - & - & - & 0.04 \\
\hline Chromic oxide & 0.25 & 0.25 & 0.25 & 0.25 \\
\hline Choline chloride & 0.20 & 0.20 & 0.20 & 0.20 \\
\hline Zinc oxide & 0.20 & 0.20 & 0.20 & 0.20 \\
\hline Vitamin-mineral premix ${ }^{2}$ & 0.50 & 0.50 & 0.50 & 0.50 \\
\hline \multicolumn{5}{|l|}{ Calculated nutrient levels (\%) } \\
\hline $\mathrm{DE}(\mathrm{MJ} / \mathrm{kg})$ & 14.18 & 14.13 & 14.18 & 14.20 \\
\hline SID lysine & 1.04 & 1.04 & 1.04 & 1.04 \\
\hline SID threonine & 0.65 & 0.65 & 0.65 & 0.65 \\
\hline SID tryptophan & 0.19 & 0.19 & 0.19 & 0.18 \\
\hline SID Methionine & 0.27 & 0.27 & 0.27 & 0.28 \\
\hline \multicolumn{5}{|l|}{ Analyzed nutrient levels (\%) } \\
\hline $\mathrm{CP}$ & 19.27 & 19.30 & 19.29 & 19.58 \\
\hline Calcium & 0.72 & 0.71 & 0.71 & 0.72 \\
\hline Total phosphorus & 0.63 & 0.63 & 0.61 & 0.62 \\
\hline
\end{tabular}

SBM, soybean meal; NFSB, fermented soybean meal produced by new strategy; CP, crude protein; DE, digestible energy; SID, standardized ileal digestibility.

${ }^{1}$ Suprotein $=$ Conversional fermented soybean meal purchased from Beijing Gold-tide Biotechnology Co., Ltd. (Beijing, China).

${ }^{2}$ Provided per kg of complete diet: $\mathrm{Mn}(\mathrm{MnO}), 47.70 \mathrm{mg} ; \mathrm{Fe}\left(\mathrm{FeSO}_{4} \cdot \mathrm{H}_{2} \mathrm{O}\right), 120 \mathrm{mg} ; \mathrm{Zn}(\mathrm{ZnO}), 103.50 \mathrm{mg} ; \mathrm{Cu}\left(\mathrm{CuSO}_{4} \cdot 5 \mathrm{H}_{2} \mathrm{O}\right), 150 \mathrm{mg} ; \mathrm{I}(\mathrm{KI}), 0.40 \mathrm{mg}$; Se $\left(\mathrm{Na}_{2} \mathrm{SeO}_{3}\right), 0.48 \mathrm{mg}$; retinyl acetate, 9,600 IU; cholecalciferol, 2,000 IU; DL- $\alpha$-tocopheryl acetate, $24 \mathrm{IU}$; menadione sodium bisulfite complex, 2.40 $\mathrm{mg}$; vitamin $\mathrm{B}_{1}, 1.50 \mathrm{mg}$; riboflavin $\mathrm{B}_{6}, 3 \mathrm{mg}$; vitamin $\mathrm{B}_{12}, 0.02 \mathrm{mg}$; pantothenic acid, $12 \mathrm{mg}$; niacin, $32 \mathrm{mg}$.

ether extract compared with NFSB. Cervantes-Pahm and Stein (2008) demonstrated that the major reason for the increased digestibility of AA in full fat soybeans compared with SBM was the presence of more ether extract in full fat soybeans.

In the present experiment, no improvement was observed in the AID or the SID of AA in NFSB compared with SBM. This observation is in agreement with Urbaityte et al. (2009), Cervantes-Pahm and Stein (2010) and Rojas and Stein (2013) who also reported that the AID and SID of AA in FSBM was similar to the values in SBM. Previously, Zhang et al. (2013) reported that with the exception of

Table 6. Energy concentration and apparent total tract digestibility (ATTD) of gross energy of soybean products fed to growing pigs (Exp. 1) ${ }^{1}$

\begin{tabular}{lccccc}
\hline Item & SBM & NFSB & Suprotein ${ }^{2}$ & PSE & p-value \\
\hline DE (MJ/kg DM) & 16.94 & 17.04 & 17.12 & 0.20 & 0.82 \\
ME (MJ/kg DM) & 16.56 & 16.51 & 16.54 & 0.31 & 0.67 \\
ATTD of GE (\%) & 89.93 & 84.90 & 87.28 & 1.43 & 0.08 \\
ME to DE ratio (\%) & 94.50 & 94.65 & 95.72 & 0.70 & 0.55 \\
\hline
\end{tabular}

SBM, soybean meal; NFSB, fermented soybean meal produced by new strategy; PSE, pooled standard error; DE, digestible energy; ME, metabolizable energy; GE, gross energy.

${ }^{1}$ Data are the means of six pigs (initial body weight of $32.2 \pm 1.7 \mathrm{~kg}$ ).

${ }^{2}$ Suprotein $=$ Conversional fermented soybean meal purchased from Beijing Gold-tide Biotechnology Co., Ltd. (Beijing, China). 
Table 7. Apparent ileal digestibility (AID) of crude protein and amino acids (\%) in soybean products fed to growing pigs (Exp. 2$)^{1}$

\begin{tabular}{|c|c|c|c|c|c|}
\hline & SBM & NFSB & Suprotein $^{2}$ & PSE & p-value \\
\hline$\overline{\mathrm{CP}}$ & $75.5^{\mathrm{b}}$ & $73.7^{b}$ & $81.6^{\mathrm{a}}$ & 0.98 & $<0.01$ \\
\hline \multicolumn{6}{|l|}{ Indispensable AA } \\
\hline Arginine & $90.3^{\mathrm{a}}$ & $87.7^{\mathrm{b}}$ & $92.4^{\mathrm{a}}$ & 0.68 & 0.01 \\
\hline Histidine & $88.3^{\mathrm{a}}$ & $84.8^{\mathrm{b}}$ & $90.4^{\mathrm{a}}$ & 0.76 & 0.01 \\
\hline Isoleucine & $82.8^{\mathrm{b}}$ & $83.2^{\mathrm{b}}$ & $88.8^{\mathrm{a}}$ & 0.89 & 0.01 \\
\hline Leucine & $84.3^{\mathrm{b}}$ & $84.7^{\mathrm{b}}$ & $89.2^{\mathrm{a}}$ & 0.55 & $<0.01$ \\
\hline Lysine & 84.0 & 79.3 & 83.6 & 1.38 & 0.12 \\
\hline Methionine & $83.8^{\mathrm{b}}$ & $84.2^{\mathrm{b}}$ & $91.0^{\mathrm{a}}$ & 1.37 & 0.03 \\
\hline Phenylalanine & $83.8^{\mathrm{b}}$ & $83.7^{\mathrm{b}}$ & $88.8^{\mathrm{a}}$ & 0.75 & $<0.01$ \\
\hline Threonine & $75.0^{\mathrm{b}}$ & $73.0^{\mathrm{b}}$ & $80.2^{\mathrm{a}}$ & 1.09 & 0.02 \\
\hline Tryptophan & $78.3^{\mathrm{b}}$ & $78.8^{\mathrm{b}}$ & $82.4^{\mathrm{a}}$ & 0.73 & 0.03 \\
\hline Valine & $80.3^{\mathrm{b}}$ & $81.0^{\mathrm{b}}$ & $86.0^{\mathrm{a}}$ & 0.74 & $<0.01$ \\
\hline Mean & $83.7^{\mathrm{b}}$ & $82.5^{\mathrm{b}}$ & $88.0^{\mathrm{a}}$ & 0.71 & $<0.01$ \\
\hline \multicolumn{6}{|l|}{ Dispensable AA } \\
\hline Alanine & $75.0^{\mathrm{b}}$ & $75.3^{\mathrm{b}}$ & $81.0^{\mathrm{a}}$ & 0.36 & $<0.01$ \\
\hline Aspartate & $82.6^{\mathrm{ab}}$ & $81.0^{\mathrm{b}}$ & $84.6^{\mathrm{a}}$ & 0.74 & $<0.01$ \\
\hline Cystine & $76.0^{\mathrm{b}}$ & $74.0^{\mathrm{b}}$ & $82.6^{\mathrm{a}}$ & 1.21 & 0.02 \\
\hline Glutamic acid & $84.3^{\mathrm{b}}$ & $83.8^{\mathrm{b}}$ & $87.6^{\mathrm{a}}$ & 0.80 & $<0.01$ \\
\hline Glycine & 65.5 & 62.0 & 68.6 & 2.23 & 0.33 \\
\hline Proline & 50.3 & 57.8 & 60.6 & 6.96 & 0.70 \\
\hline Serine & $81.9^{\mathrm{a}}$ & $79.0^{\mathrm{b}}$ & $83.0^{\mathrm{a}}$ & 0.75 & $<0.01$ \\
\hline Tyrosine & $80.9^{\mathrm{b}}$ & $79.2^{\mathrm{b}}$ & $85.8^{\mathrm{a}}$ & 0.71 & $<0.01$ \\
\hline Mean & $75.3^{\mathrm{b}}$ & $73.2^{\mathrm{b}}$ & $82.4^{\mathrm{a}}$ & 1.62 & 0.03 \\
\hline All AA & $79.0^{\mathrm{b}}$ & $77.3^{\mathrm{b}}$ & $84.6^{\mathrm{a}}$ & 0.92 & $<0.01$ \\
\hline
\end{tabular}

SBM, soybean meal; NFSB, fermented soybean meal produced by new strategy; PSE, pooled standard error; CP, crude protein; AA, amino acids.

${ }^{1}$ Data are the means of eight pigs (initial body weight of $26.8 \pm 1.5 \mathrm{~kg}$ ) used in a replicated $4 \times 4$ Latin square design.

${ }^{2}$ Suprotein $=$ Conversional fermented soybean meal purchased from Beijing Gold-tide Biotechnology Co., Ltd. (Beijing, China).

${ }^{\mathrm{ab}}$ Means followed by same or no letter do not differ $(\mathrm{p}>0.05)$.

histidine, leucine, isoleucine, lysine, threonine, alanine and glycine, there were no differences in the SID of AA between FSBM and SBM. However, it has been reported that the AID of most AA in FSBM is greater than in SBM (Yun et al., 2005). Differences in starter strains, fermentation conditions, and drying methods might contribute to the different digestibility of AA of NFSB and the increased effect of fermentation may only be observed with some AA instead of all AA.

In Exp. 3 we observed that pigs fed diets with $12 \%$ NFSB and 12\% Suprotein-12 had similar ADG and ADFI compared with pigs in the control group. However, ADG and ADFI of pigs fed a diet with $6 \%$ NFSB were significantly higher than those in the control group $(\mathrm{p}<0.05)$, which suggests that fermentation of SBM eliminates possible adverse effects of feeding SBM to nursery piglets. The reason for the greater ADG and ADFI of pigs fed a diet with $6 \%$ NFSB may be that during fermentation, the concentration of glycinin and $\beta$-conglycinin were decreased. Glycinin and $\beta$-conglycinin are potential antigenic and allergenic compounds for nursery piglets, causing villus atrophy and crypt hyperplasia in the small intestine (Li et al., 1990). Thus, reduction of glycinin and $\beta$-conglycinin in
SBM can be beneficial to nursery pigs. In addition, improvements in performance of weaning pig were reported when organic acids were added to pig feeds (Kil et al., 2006). In the present study, lactic acid presented in the FSBM products may also contribute to greater ADG and ADFI in piglets fed a diet with $6 \%$ NFSB. Furthermore, FSBM products used in this study contained greater percentage of small peptides that are thought to be absorbed more easily (Gilbert et al., 2008). The combination of a better nutritional status and a reduced immunological challenge when piglets were fed FSBM products might help to improve performance. When NFSB replaced an equal amount of SBM up to $12 \%$, growth of pigs was not improved compared with pigs fed 6\% NFSB. This observation is in agreement with Kim et al. (2007), who also reported that growth of pigs was not improved when FSBM replaced an equal amount of SBM up to $9 \%$. Therefore, the mode of action of the addition amount of FSBM remains to be investigated.

In conclusion, fermentation with the new strategy of coculture Bacillus subtilis MA139 with Streptococcus thermophilus and Saccharomyces cerevisae did not affect the energy value and SID of AA in SBM. Use of NFSB to 
Table 8. Standardized ileal digestibility (SID) of crude protein and amino acids (\%) in soybean products fed to growing pigs (Exp. 2$)^{1}$

\begin{tabular}{|c|c|c|c|c|c|}
\hline & SBM & NFSB & Suprotein $^{2}$ & PSE & p-value \\
\hline$\overline{\mathrm{CP}}$ & $82.8^{\mathrm{b}}$ & $80.5^{b}$ & $88.6^{\mathrm{a}}$ & 0.94 & $<0.01$ \\
\hline \multicolumn{6}{|l|}{ Indispensable AA } \\
\hline Arginine & $93.5^{\mathrm{a}}$ & $90.8^{\mathrm{b}}$ & $95.4^{\mathrm{a}}$ & 0.66 & 0.01 \\
\hline Histidine & $91.2^{\mathrm{a}}$ & $87.8^{\mathrm{b}}$ & $93.0^{\mathrm{a}}$ & 0.77 & 0.02 \\
\hline Isoleucine & $86.7^{\mathrm{b}}$ & $86.5^{\mathrm{b}}$ & $92.4^{\mathrm{a}}$ & 1.24 & 0.01 \\
\hline Leucine & $87.8^{\mathrm{b}}$ & $88.0^{\mathrm{b}}$ & $92.8^{\mathrm{a}}$ & 0.69 & $<0.01$ \\
\hline Lysine & 87.8 & 83.2 & 87.2 & 1.36 & 0.12 \\
\hline Methionine & $87.7^{\mathrm{b}}$ & $87.5^{\mathrm{b}}$ & $94.2^{\mathrm{a}}$ & 1.27 & 0.03 \\
\hline Phenylalanine & $87.7^{\mathrm{b}}$ & $87.2^{\mathrm{b}}$ & $92.4^{\mathrm{a}}$ & 0.71 & $<0.01$ \\
\hline Threonine & $83.7^{\mathrm{b}}$ & $81.0^{\mathrm{b}}$ & $88.0^{\mathrm{a}}$ & 1.12 & 0.02 \\
\hline Tryptophan & $84.0^{\mathrm{b}}$ & $83.8^{\mathrm{b}}$ & $87.6^{\mathrm{a}}$ & 0.66 & 0.02 \\
\hline Valine & $86.3^{\mathrm{b}}$ & $86.5^{\mathrm{b}}$ & $91.6^{\mathrm{a}}$ & 0.71 & $<0.01$ \\
\hline Mean & $88.3^{\mathrm{b}}$ & $86.8^{\mathrm{b}}$ & $91.6^{\mathrm{a}}$ & 0.82 & 0.03 \\
\hline \multicolumn{6}{|l|}{ Dispensable AA } \\
\hline Alanine & $82.8^{\mathrm{b}}$ & $82.3^{\mathrm{b}}$ & $87.6^{\mathrm{a}}$ & 0.49 & $<0.01$ \\
\hline Aspartate & 86.8 & 85.2 & 89.6 & 0.84 & 0.07 \\
\hline Cystine & $85.8^{\mathrm{b}}$ & $83.2^{\mathrm{b}}$ & $91.4^{\mathrm{a}}$ & 1.11 & 0.02 \\
\hline Glutamic acid & $87.2^{\mathrm{b}}$ & $86.2^{\mathrm{b}}$ & $92.2^{\mathrm{a}}$ & 0.88 & 0.01 \\
\hline Glycine & 80.5 & 76.0 & 81.6 & 2.23 & 0.40 \\
\hline Proline & 75.8 & 79.8 & 77.0 & 1.84 & 0.61 \\
\hline Serine & $87.3^{\mathrm{ab}}$ & $84.8^{\mathrm{b}}$ & $90.0^{\mathrm{a}}$ & 0.71 & 0.01 \\
\hline Tyrosine & $84.8^{\mathrm{b}}$ & $86.3^{\mathrm{b}}$ & $93.0^{\mathrm{a}}$ & 0.67 & $<0.01$ \\
\hline Mean & $82.7^{\mathrm{b}}$ & $80.2^{\mathrm{b}}$ & $89.2^{\mathrm{a}}$ & 1.59 & 0.03 \\
\hline All AA & $85.2^{\mathrm{b}}$ & $82.8^{\mathrm{b}}$ & $90.4^{\mathrm{a}}$ & 0.93 & $<0.01$ \\
\hline
\end{tabular}

SBM, soybean meal; NFSB, fermented soybean meal produced by new strategy; PSE, pooled standard error; CP, crude protein; AA, amino acids.

${ }^{1}$ Data are the means of eight pigs (initial body weight of $26.8 \pm 1.5 \mathrm{~kg}$ ) used in a replicated $4 \times 4$ Latin square design.

${ }^{2}$ Suprotein $=$ Conversional fermented soybean meal purchased from Beijing Gold-tide Biotechnology Co., Ltd. (Beijing, China)

${ }^{a b}$ Means followed by same or no letter do not differ ( $\left.p>0.05\right)$.

Table 9. Performance of nursery pigs fed diets with fermented soybean meal products replacing soybean meal (Exp. 3$)^{1}$

\begin{tabular}{|c|c|c|c|c|c|c|}
\hline & SBM & NFSB-6 & NFSB-12 & Suprotein-12 & $\mathrm{PSE}^{2}$ & $\mathrm{p}$-value \\
\hline \multicolumn{7}{|l|}{ BW (kg) } \\
\hline Initial & 8.86 & 8.88 & 8.85 & 8.87 & 0.09 & 1.00 \\
\hline d 14 & 14.44 & 14.68 & 14.60 & 14.51 & 0.16 & 0.71 \\
\hline $\mathrm{d} 28$ & 21.25 & 22.06 & 21.63 & 21.42 & 0.21 & 0.07 \\
\hline \multicolumn{7}{|l|}{ d 1 to 14} \\
\hline ADG (g) & 398 & 414 & 411 & 403 & 7.80 & 0.48 \\
\hline ADFI (g) & 640 & 679 & 652 & 638 & 25.61 & 0.64 \\
\hline $\mathrm{G}: \mathrm{F}$ & 0.63 & 0.62 & 0.64 & 0.64 & 0.03 & 0.93 \\
\hline \multicolumn{7}{|l|}{ d 15 to 28} \\
\hline ADG $(\mathrm{g})$ & $487^{\mathrm{b}}$ & $528^{\mathrm{a}}$ & $502^{\mathrm{ab}}$ & $494^{\mathrm{b}}$ & 9.09 & 0.03 \\
\hline ADFI (g) & $905^{\mathrm{b}}$ & $991^{\mathrm{a}}$ & $896^{\mathrm{b}}$ & $936^{\mathrm{ab}}$ & 20.38 & 0.02 \\
\hline G:F & 0.54 & 0.53 & 0.56 & 0.53 & 0.01 & 0.33 \\
\hline \multicolumn{7}{|l|}{ d 1 to 28} \\
\hline ADG (g) & $442^{\mathrm{b}}$ & $471^{\mathrm{a}}$ & $457^{\mathrm{ab}}$ & $449^{\mathrm{b}}$ & 5.62 & 0.01 \\
\hline ADFI (g) & 772 & 835 & 774 & 787 & 19.69 & 0.12 \\
\hline $\mathrm{G}: \mathrm{F}$ & 0.58 & 0.57 & 0.59 & 0.57 & 0.01 & 0.68 \\
\hline
\end{tabular}

SBM, Soybean meal; NFSB, fermented soybean meal produced by new strategy; Suprotein, conversional fermented soybean meal; PSE, pooled standard error; BW, body weight; ADG, average daily gain; ADFI, average daily feed intake; G:F, gain-to-feed ratio.

${ }^{1}$ A total of 144 crossbred pigs (Duroc $\times$ Landrace $\times$ Large White; initial BW of $8.8 \pm 1.2 \mathrm{~kg}$ ) were allotted to provide six pigs per pen and six pens per treatment.

${ }^{a b}$ Means followed by same or no letter do not differ ( $\left.p>0.05\right)$. 
replace $6 \%$ SBM improved the ADFI and ADG of nursery piglets.

\section{ACKNOWLEDGMENTS}

This research was supported by NSFC (31372316) and the Special Public Sector Fund in Agriculture (200903006) of China.

\section{REFERENCES}

Adeola, O. 2001. Digestion and balance techniques in pigs. In: Swine Nutrition (Ed. A. J. Lewis and L. L. Southern). CRC Press, Washington, DC. pp. 903-916.

AOAC. 2000. Official Methods of Analysis. 17th edn. Association of Official Analytical Chemists, Arlington, VA, USA.

Cervantes-Pahm, S. K. and H. H. Stein. 2008. Effect of dietary soybean oil and soybean protein concentration on the concentration of digestible amino acids in soybean products fed to growing pigs. J. Anim. Sci. 86:1841-1849.

Cervantes-Pahm, S. K. and H. H. Stein. 2010. Ileal digestibility of amino acids in conventional, fermented, and enzyme-treated soybean meal and in soy protein isolate, fish meal, and casein fed to weanling pig. J. Anim. Sci. 88:2674-2683.

Chiang, G., W. Q. Lu, X. S. Piao, J. K. Hu, L. M. Gong, and P. A. Thacker. 2010. Effects of feeding solid-state fermented rapeseed meal on performance, nutrient digestibility, intestinal ecology and intestinal morphology of broiler chickens. Asian Australas. J. Anim. Sci. 23:263-271.

Cranwell, P. D. 1985. The development of the stomach in the pig: The effect of age and weaning. I. Stomach size, muscle and zones of mucosa. In: Proceedings of 3rd International Seminar on Digestive Physiology in the Pig, Copenhagen, Denmark. pp. 112.

Cronwell, G. L. 2012. Soybean meal: An exceptional protein source. Soybean Meal INFOcenter. http://www.soymeal.org Accessed September 28, 2013.

Egounlety, M. and O. C. Aworh. 2003. Effect of soaking, dehulling, cooking and fermentation with Rhizopus oligosporus on the oligosaccharides, trypsin inhibitor, phytic acid and tannins of soybean (Glycine max Merr.), cowpea (Vigna unguiculata L. Walp) and groundbean (Macrotyloma geocarpa Harms). J. Food Eng. 56:249-254.

Evans, R. J. and H. A. Butts. 1948. Studies on heat inactivation of lysine in soy bean oil meal. J. Biol. Chem. 175:15-20.

Feng, J., X. Liu, Z. R. Xu, Y. P. Lu, and Y. Y. Liu. 2007. The effect of Aspergillus oryzae fermented soybean meal on growth performance, digestibility of dietary components and activities of intestinal enzymes in weaned piglets. Anim. Feed Sci. Technol. 134:295-303.

Frias, J., Y. S. Song, C. Martinez-Villaluenga, E. Gonzalez de Mejia, and C. Vidal-Valverde. 2008. Immunoreactivity and amino acid content of fermented soybean products. J. Agric. Food Chem. 56:99-105.

Gilbert, E. R., E. A. Wong, and K. E. Webb Jr. 2008. Peptide absorption and utilization: Implications for animal nutrition and health. J. Anim. Sci. 86:2135-2155.

Goebel, K. P. and H. H. Stein. 2011. Phosphorus digestibility and energy concentration of enzyme-treated and conventional soybean meal fed to weanling pigs. J. Anim. Sci. 89:764-772.

Guo, X. H., D. F. Li, W. Q. Lu, X. S. Piao, and X. L. Chen. 2006. Screening of Bacillus strains as potential probiotics and subsequent confirmation of the in vivo effectiveness of Bacillus subtilis MA139 in pigs. Antonie van Leeuwenhoek 90:139-146.

Hong, K. J., C. H. Lee, and S. W. Kim. 2004. Aspergillus oryzae GB-107 fermentation improves nutritional quality of food soybeans and feed soybean meals. J. Med. Food 7:430-435.

Hu, J. K., W. Q. Lu, C. L. Wang, R. H. Zhu, and J. Y. Qiao. 2008. Characteristics of solid-state fermented feed and its effects on performance and nutrient digestibility in growing-finishing pigs. Asian Australas. J. Anim. Sci. 21:1635-1641.

Kil, D. Y., L. G. Piao, H. F. Long, J. S. Lim, M. S. Yun, C. S. Kong, W. S. Ju, H. B. Lee, and Y. Y. Kim. 2006. Effects of organic or inorganic acid supplementation on growth performance, nutrient digestibility and white blood cell counts in weanling pigs. Asian Australas. J. Anim. Sci. 19:252-261.

Kim, B. G. and H. H. Stein. 2009. A spreadsheet program for making a balanced Latin square design. Rev. Colomb. Cienc. Pecu. 22:591-596.

Kim, Y. G., J. D. Lohakare, J. H. Yun, S. Heo, and B. J. Chae. 2007. Effect of feeding levels of microbial fermented soy protein on the growth performance, nutrient digestibility and intestinal morphology in weaned piglets. Asian Australas. J. Anim. Sci. 20:399-404.

Kim S. W., E. van Heugten, F. Ji, C. H. Lee, and R. D. Mateo. 2010. Fermented soybean meal as a vegetable protein source for nursery pigs: I. Effects on growth performance of nursery pigs. J. Anim. Sci. 88:214-224.

Lalles, J. P., H. M. Tukur, R. Toullec, and B. G. Miller. 1996. Analytical criteria for predicting apparent digestibility of soybean protein in preruminant calves. J. Dairy Sci. 79:475482

Lenis, N. P., P. Bikker, J. van der Meulen, J. T. van Diepen, J. G. Bakker, and A. W. Jongbloed. 1996. Effects of dietary neutral detergent fiber on ileal digestibility and portal flux of nitrogen an amino acids and on nitrogen utilization in growing pigs. J. Anim. Sci. 74:2687-2699.

Li, D. F., J. L. Nelssen, P. G. Reddy, F. Blecha, J. D. Hancock, G. L. Allee, R. D. Goodband, and R. D. Klemm. 1990. Transient hypersensitivity to soybean meal in the early-weaned pig. J. Anim. Sci. 68:1790-1799.

Liu, X., J. Feng, Z. R. Xu, Y. P. Lu, and Y. Y. Liu. 2007. The effects of fermented soybean meal on growth performance and immune characteristics in weaned piglets. Turk. J. Vet. Anim. Sci. 31:341-345.

Ma, X., P. Sun, P. L. He, P. F. Han, J. J. Wang, S. Y. Qiao, and D. F. Li. 2010. Development of monoclonal antibodies and a competitive ELISA detection method for glycinin, an allergen in soybean. Food Chem. 121:546-551.

Noblet, J. and Y. Henry. 1993. Energy evaluation system for pig diets: A review. Livest. Prod. Sci. 36:121-141.

NRC. 1998. Nutrient Requirements of Swine, 10th ed. National Academy Press, Washington, DC, USA.

NRC. 2012. Nutrient Requirements of Swine. 11th ed. National Academy Press, Washington, DC, USA.

Qiao, J. Y., B. Dong, Y. H. Li, B. Zhang, and Y. H. Cao. 2009. 
Cloning of a $\beta$-1,3-1,4-glucanase gene from Bacillus subtilis MA139 and its functional expression in Escherichia coli. Appl. Biochem. Biotechnol. 152:334-342.

Qiao, J. Y., Z. H. Rao, B. Dong, and Y. H. Cao. 2010. Expression of Bacillus subtilis MA139 $\beta$-mannanase in Pichia pastoris and the enzyme characterization. Appl. Biochem. Biotechnol. 160:1362-1370.

Refstie, S., S. Sahlstrom, E. Brathen, G. Baeverfjorda, and P. Krogedal. 2005. Lactic acid fermentation eliminates indigestible carbohydrates and antinutritional factors in soybean meal for Atlantic salmon (Salmo salar). Aquaculture 246:331-345

Ren, P., Z. P. Zhu, B. Dong, J. J. Zang, and L. M. Gong. 2011. Determination of energy and amino acid digestibility in growing pigs fed corn distillers' dried grains with solubles containing different lipid levels. Arch. Anim. Nutr. 65:303-319.

Rojas, O. J. and H. H. Stein. 2013. Concentration of digestible, metabolizable, and net energy and digestibility of energy and nutrients in fermented soybean meal, conventional soybean meal, and fish meal fed to weanling pigs. J. Anim. Sci. 91:4397-4405.

Schägger, H. 2006. Tricine-SDS-PAGE. Nat. Protoc. 1:16-22.

Singhania, R. R., A. K. Patel, C. R. Soccol, and A. Pandey. 2009. Recent advances in solid-state fermentation. Biochem. Eng. J. 44:13-18.

Song, G. L., D. F. Li, X. S. Piao, F. Chi, and W. J. Yang. 2003. Apparent ileal digestibility of amino acids and the digestible and metabolizable energy content of high-oil corn varieties and its effects on growth performance of pigs. Arch. Anim. Nutr. 57:297-306.

Stein, H. H., C. F. Shipley, and R. A. Easter. 1998. Technical note: A technique for inserting a T-cannula into the distal ileum of pregnant sows. J. Anim. Sci. 76:1433-1436.

Stein, H. H., B. Seve, M. F. Fuller, P. J. Moughan, and C. F. M. de Lange. 2007. Invited review: Amino acid bioavailability and digestibility in pig feed ingredients: terminology and application. J. Anim. Sci. 85:172-180.

Urbaityte, R., R. Mosenthin, M. Eklund, H. Piepho, N. Sauer, and M. Rademacher. 2009. Standardised ileal crude protein and amino acid digestibilities in protein supplements for piglets. Arch. Anim. Nutr. 63:356-378.
Van Soest, P. J., J. B. Robertson, and B. A. Lewis. 1991. Methods for dietary fiber and non-starch polysaccharides in relation to animal nutrition. J. Dairy Sci. 74:3568-3597.

Waldroup, P. W. 2012. Soybean meal: Demand. Soybean Meal INFOcenter. http://www.soymeal.org Accessed September 28, 2013.

West, J. L. 2004. Modification of materials with bioactive peptides. In: Methods in Molecular Biology (Ed. A. P. Hollander and P. V. Hatton). Humana Press, Totowa. pp. 113-121.

Williams, C. H., D. J. David, and O. Iismaa. 1962. The determination of chromic oxide in faeces sample by atomic absorption spectrophotometry. J. Agric. Sci. 59:381-385.

Woodworth, J. C., M. D. Tokach, R. D. Goodband, J. L. Nelssen, P. R. O'Quinn, D. A. Knabe, and N. W. Said. 2001. Apparent ileal digestibility of amino acids and the digestible and metabolizable energy content of dry extruded-expelled soybean meal and its effects on growth performance of pigs. J. Anim. Sci. 79:1280-1287.

Ying, W., R. Zhu, W. Lu, and L. Gong. 2009. A new strategy to apply Bacillus subtilis MA139 for the production of solid-state fermentation feed. Lett. Appl. Microbiol. 49: 229-234.

You, J. M., D. F. Li, S. Y. Qiao, Z. R. Wang, P. L. He, D. Y. Ou, and B. Dong. 2008. Development of a monoclonal antibodybased competitive ELISA for detection of $\beta$-conglycinin, an allergen from soybean. Food Chem. 106:352-360.

Yun, J. H., I. K. Kwon, J. D. Lohakare, J. Y. Choi, J. S. Yong, J. Zheng, W. T. Cho, and B. J. Chae. 2005. Comparative efficacy of plant and animal protein sources on the growth performance, nutrient digestibility, morphology, and caecal microbiology of early-weaned pigs. Asian Australas. J. Anim. Sci. 18:12851293.

Zhang, H. Y., J. Q. Yi, X. S. Piao, P. F. Li, Z. K. Zeng, D. Wang, L. Liu, G. Q. Wang, and X. Han. 2013. The metabolizable energy value, standardized ileal digestibility of amino acids in soybean meal, soy protein concentrate and fermented soybean meal, and the application of these products in early-weaned piglets. Asian Australas. J. Anim. Sci. 26:691-699. 